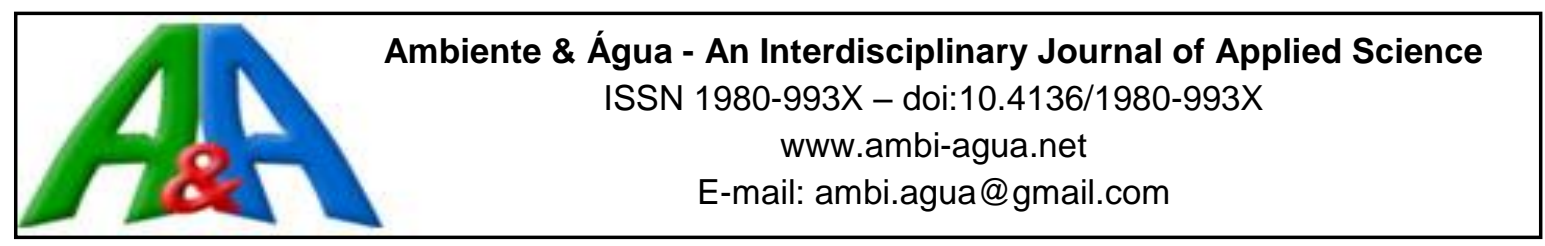

\title{
Urban solid waste challenges in the BRICS countries: a systematic literature review
}

\author{
ARTICLES doi:10.4136/ambi-agua.2157
}

Received: 06 Jul. 2017; Accepted: 23 Jan. 2018

\begin{abstract}
Andriani Tavares Tenório Gonçalves*; Flávia Tuane Ferreira Moraes; Guilherme Lima Marques; Josiane Palma Lima; Renato da Silva Lima
\end{abstract}

\author{
Universidade Federal de Itajubá (UNIFEI), Itajubá, MG, Brasil \\ Instituto de Engenharia de Produção e Gestão (IEPG). E-mail: andriani_dri@yahoo.com.br, \\ flaviatuane@yahoo.com.br, limarques8@gmail.com,jpalmalima@gmail.com,rslima74@gmail.com \\ *Corresponding author
}

\begin{abstract}
Urban Solid Waste Management (USWM) is a worldwide challenge. The problems faced are even greater due to the disproportional increase of Urban Solid Waste (USW) generation in volume, especially in a context of increased urbanization, population growth and economic globalization in the BRICS countries (Brazil, Russia, India, China and South Africa). In this context, the objective of this work is to analyze the status of MSW management in the BRICS countries, as well as to promote an exchange of experience and management strategies, pointing out possible ways to improve USWM systems that have to be adapted to each local reality. Focusing on this, a systematic literature revision was carried out through a bibliometric analysis. Results showed that the management system of these BRICS countries does not possess well-developed structures. The collection stage is quite often inefficient, the solid waste being stored in inappropriate ways and also disposed of in irregular locations. The participation of the informal sector is a trademark characteristic in USWM for BRICS countries, highlighting the need to integrate and formalize these activities for USW collection. Due to the high organic fraction, it is known that composting offers advantages as a way to promote a better use of organic waste and also as a means of reducing the amount of waste sent to sanitary landfills. Finally, with a better knowledge about solid waste generation and decentralization of the offered services, the decision makers will be able to successfully provide this essential public service.
\end{abstract}

Keywords: BRICS, systematic literature review, urban solid waste management (USWM).

\section{Os desafios da gestão de resíduos sólidos urbanos nos países do BRICS: uma revisão sistemática de literatura}

\section{RESUMO}

A Gestão de Resíduos Sólidos Urbanos (GRSU) é um desafio mundial. Com o rápido processo de urbanização, crescimento populacional e econômico nos países pertencentes ao BRICS (Brasil, Rússia, Índia, China e África do Sul) o desafio é ainda maior, decorrente do aumento do volume de Resíduos Sólidos Urbanos (RSU) gerados por esses processos. Neste contexto, o presente trabalho tem por objetivo analisar o status da gestão dos RSU nos países do BRICS, bem como promover um intercâmbio de experiência e estratégias de gestão, 
apontando possíveis caminhos para melhorar os sistemas de GRSU, cuja a implementação deve ser adaptada à realidade de cada país. Para isso, foi realizada uma revisão sistemática de literatura a partir de uma análise bibliométrica. Os resultados mostraram que os sistemas de gestão de RSU nos países membros do BRICS não apresentam uma estrutura bem desenvolvida, muitas vezes a coleta não é eficiente, os resíduos são armazenados de maneira imprópria e destinados em áreas irregulares. A participação do setor informal é característica marcante na GRSU dos países do BRICS, notando-se, portanto, a necessidade de integração do setor informal ao sistema formal de coleta destes resíduos. Devido à alta fração orgânica, é notória as vantagens da compostagem como forma de aproveitamento dos resíduos orgânicos e como meio de reduzir a quantidade de resíduos enviados a aterros. O conhecimento da geração de RSU e a descentralização dos serviços oferecidos de GRSU possibilitaria um maior êxito no atendimento à população.

Palavras-chave: BRICS, gestão de resíduos sólidos urbanos (GRSU), revisão sistemática de literatura.

\section{INTRODUCTION}

Urban Solid Waste (USW) is made up of residuals and byproducts from domestic activities, street sweeping, and household and public cleaning (Loureiro et al., 2013; Santiago e Dias, 2012; Singh et al., 2014). The increased generation of USW is a growing concern in cities worldwide (Patel et al., 2010), mainly due to the fact that specific municipal management strategies have become more necessary.

Urban Solid Waste Management (USWM) is a multi-disciplinary activity which includes the generation, separation, storage, collection, transportation, processing, recovery and disposal of these materials (Rada et al., 2013). It involves the cooperation of many stakeholders who make up the municipality, as well as the population and local authorities for the pertinent activities (Chen, 2010). The main objective in USWM is to protect public health and the environment through conservation of natural resources (Allesch and Brunner, 2014).

Thus, USWM has become an international challenge, especially in urban areas of developing countries (Jin et al., 2006; Sharholy et al., 2008; Damghani et al., 2008). Rapid urbanization has been seen in these nations, especially in the BRICS (Brazil, Russia, India, China and South Africa), over the last three decades (Wang et al., 2016). This urbanization has sparked a significant growth in waste material. The main reason for this magnitude of growth in USW is related to the Gross Domestic Product (GDP), industrialization, population growth (Linzner and Salhofer, 2014), along with urbanization and an overall increase in living standards (Batool et al., 2008).

Generation rates for USW are influenced by economic development, industrialization levels, public habits and local climate (Hoornweg and Bhada-Tata, 2012). From this perspective, according to the Human Development Report (UNDP, 2015), Russia, Brazil, and China have a very similar Human Development Index (HDI) (0.804, 0.754, and 0.738, respectively), classifying these countries with an elevated score for human development. Furthermore, the report classified South Africa and India as countries of medium human development (0.666 and 0.624, respectively). Further, according to the Ministry of Foreign Affairs (Brazil, 2014), these countries, taken together, account for 19.8\% of world GDP and $41.6 \%$ of the total global population.

In analyzing BRICS legislation about USWM, it is possible to see that they are seeking solutions to the problem of solid waste. In Brazil, the National Solid Waste Policy (Brazil, 2010) and, in India, the Municipal Solid Waste (Management and Handling - 2000) are examples of laws that seek to create guidelines regarding the collection, separation, storage, transport process and final disposal of MSW. Although the BRICS countries are regulating 
USWM, the standards often do not fit the local reality. According to Tai et al. (2011), in China, specific laws (Prevention of Environmental Pollution Caused by Solid Waste and Administrative Measures for Urban Living Garbage) have not achieved expected effects, since the goals were ambitious, making these laws impossible to be applied by the responsible departments. Massod et al. (2014) argue that misapplication of laws is the main reason for the poor USWM efficiency.

Based on the data above, studies directed to USWM in BRICS are important to aid countries in the process of adapting to the rapid changes, which are ongoing in the national territories. For this reason, it is necessary to guide decision-making about the best strategies to adopt in each country, promoting an exchange of experiences and management policies. Thus, the purpose of this article is to understand the management of USW in the BRICS countries, through a systematic review of literature based on a bibliometric analysis.

This article is structured in the following manner: after this introduction, Section 2 presents the methodology. Section 3 presents results and discussion. Recommendations are given in Section 4, and conclusions are provided in Section 5, followed by the bibliographic references.

\section{RESEARCH METHODOLOGY}

The bibliometric methodology is used as a means of comparing and quantifying scientific productions based on the process of data aggregation analysis such as year of publication, countries, publication names, authors and citations, among other things (Sun and Grimes, 2016). Citation studies for scientific articles have important implications for greater understanding of the knowledge accumulation process as well as for the research applications in many different fields of knowledge (Walters, 2011). For these reasons, this methodology presents itself as a significant method for mapping scientific processes and as a tool for selecting the best articles to carry out SLR.

The Systematic Literature Review (SLR) is an instrument to map published studies on specific topics so that the researcher can elaborate and synthesize knowledge about the subject of study (Biolchini et al., 2007). The study is carried out according to a previously established protocol which can be replicated by other professionals, who will be able to evaluate the chosen patterns for the case; it differs from traditional reviews because it adopts a replicable process which is scientific, transparent and aids in developing guidelines for searching, selecting, critical analysis and synthesis of results (Cook et al., 1997).

For the means of this study, the SLR procedure from Brereton et al. (2007) and Biolchini et al. (2007) was adopted. According to these authors, the development of an SLR is made up of three phases: Planning, Execution and Results Analysis. In the first phase, the study protocol must be developed, including the main objective, the methods to be used and the criteria to be adopted in selecting the articles (Biolchini et al., 2007). The second phase of the process, the execution, involves the search for information, material selection and evaluation. The research method and criteria for inclusion and exclusion of publications should be rigidly adhered to, as each one is defined in the research protocol (Biolchini et al., 2007). The third and final phase consists of the analysis of all the information considered relevant for the study's objective, which should be collected and stored in a synthetic form. Although the SLR process seems sequential, it involves iterations. Some activities may start during the protocol development and only later will be defined, just when they are ready to be put into practice (Biolchini et al., 2007).

\subsection{Execution of Bibliometric Analysis and Systematic Literature Review}

\subsubsection{Planning}

The database used in this research was the ISI Web of Knowledge (Web of Science), which is an indexed database that allows users to export the metadata necessary for the bibliometric 
analysis. The keywords used in the search were "Municipal Solid Waste Management" and "Urban Solid Waste Management" from 2006 to 2016. In the Web of Science (WoS) platform, the search resulted in a total sample, for both keywords, of 3214 publications of thematic and environmental areas, mainly related to Environmental Science and Environmental Engineering.

For this first phase of the planning, a bibliometric analysis was performed using the HistCite software with data from 3214 articles. From the publications imported into the software, the results were evaluated under the following aspects: number of publications per year (Figure 1), number of articles per journal (Table 1) and citation analysis.

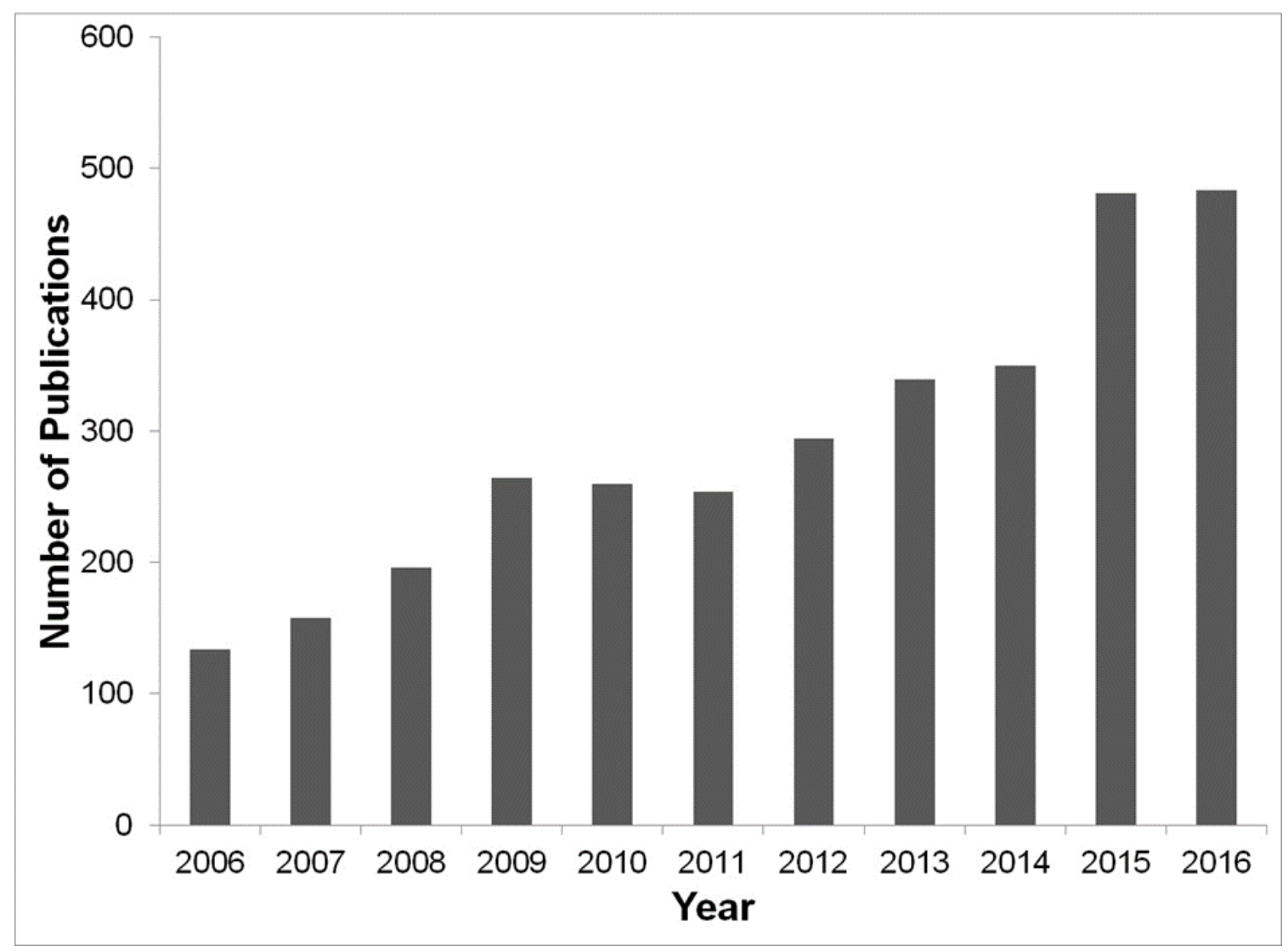

Figure 1. Number of publications per year.

Table 1. Number of Publications, TGCS and JCR for each journal.

\begin{tabular}{lccc}
\hline \multicolumn{1}{c}{ Journals } & Number of Publications & TGCS & JCR \\
\hline Waste Management & 509 & 8954 & 3,829 \\
Waste Management \& Research & 235 & 1862 & 1,338 \\
Resources Conservation and Recycling & 153 & 1880 & 3,280 \\
Journal of Cleaner Production & 91 & 1118 & 4,959 \\
Journal of Environmental Management & 67 & 1397 & 3,131 \\
Environmental Engineering and Management & 46 & 255 & 1,008 \\
Journal & 46 & 547 & 6,798 \\
Renewable \& Sustainable Energy Reviews & 42 & 1124 & 4,836 \\
Journal of Hazardous Materials & & & \\
\hline
\end{tabular}

The number of publications in USWM has grown over the years (Figure 1) due to an increase of waste generation and management expenses. According to projections from the World Bank, the generation and expenses related to these materials have advanced significantly 
since 2010. In a timeframe of 15 years, it is forecast that USW will jump by $42 \%$ in 161 countries $(3,532,255$ tons/day in 2010 to $6,069,705$ tons/day in 2025), while costs related to USWM will expand by 45\% (\$205.4 billion in 2010 to $\$ 375$ billion in 2025) (Hoornweg and Bhada-Tata, 2012). Thus, with the increase of the generation and public expenses with USWM, research is necessary to develop new strategies and policies.

The 3214 articles were published in 820 journals, the 10 most published journals are presented in Table 1. The Total Global Citation Score (TGCS) of each journal, which represents the total number of citations per journal on the WoS platform among the analyzed publications, is presented and indicates their reachability. The Journal Citation Reports (JCR), also presented in this research, indicates the average number of citations received by the periodical publications of the journal of the previous two years.

The goal of this research is to evaluate how the USW management occurs in the BRICS countries, following an SLR from the collection of 3214 articles searched on the WoS platform. In this way, it is possible to verify the current status of USW generation and also to propose better practices in order to leverage management efficiency. From this objective, some research questions (RQ) were formulated so as to guide the analysis and identify the USW generation gaps:

RQ1: What is the generation and composition of USW?

RQ2: How is the storage of waste carried out?

RQ3: How are the waste collection, transfer, and transportation performed?

RQ4: What are the main types of treatment and final disposal of USW?

RQ5: Is the USW management in the BRICS countries carried out in a decentralized or centralized manner?

RQ6: What are the improvements actions related to USWM adopted by the BRICS countries?

After developing the research questions (RQ) and the objective of the SLR, the research protocol was established based on two pillars: (1) criteria, related to the composition and construction of articles such as year of publication, country, language, title, abstract and keywords; and (2) perspectives, which refers to the basis of a good USW generation, in other words, generation, composition, storage, collection, transfer, transportation, treatment, and final disposal.

\subsubsection{Execution}

Through the collection of 3214 articles searched on the WoS platform, the following search filters were applied to perform the SLR: type of document, in which only articles were selected, mainly because of the peer review processes that they go through in their full version; consequently, the database returned a total of 2493 articles. Only English-language articles were selected, decreasing the selection to a total of 2396 articles. The later selection criteria were related to countries, where the BRICS countries were selected: China, India, Brazil, South Africa and Russia. With these filters applied, the sample for the WoS platform was reduced to 558 publications. These articles were also submitted to the selection filter, which included the application of the inclusion criteria by the process of reading the title, abstract and keywords. Only articles in the context of urban solid waste management were selected, thus reducing the sample to 46 articles submitted for review.

\subsubsection{Result Analysis}

Finally, the 46 articles selected, with USW generation in the BRICS countries presented, were subjected to exhaustive reading and analysis aimed to answer the six research questions 
generated in the planning stage of the SLR. Tables with summary information of the articles were developed aiming to present data of how USW management, by country, is made. Also, the general management view allows the exchange of experience and management strategies among countries, seeking to identify the points to be improved. Along these lines, the review sought to present the status of MSW management in the five BRICS countries by analysing the pillar of the perspectives outlined in the planning stage.

\section{RESULTS AND ANALYSIS OF THE SYSTEMATIC LITERATURE REVIEW}

Urban Solid Waste Management is made up of six basic services: Storage, Collection, Transfer and Transportation; Processing/Treatment and, finally, Disposal of materials which cannot be recovered economically for recycling or reuse. Furthermore, according to Patel et al. (2010), to implement a correct USWM policy, the quantity and composition of the USW must be known.

Thus, the results of the SLR are presented and analyzed first in terms of generation and composition (Table 2), then, according to each one of the USWM activities (storage, collection, transfer, transportation, treatment, and final disposal) for the BRICS countries (Table 3 and Table 7).

\subsection{Generation and Composition of USW}

According to Abduli et al. (2013), it is essential to comprehend the quantity and type of USW generated in order to plan and develop a suitable management policy for these materials in a specific location. Moreover, the lack of knowledge, mainly about MSW quantity and its characteristics, can make some stages not viable, such as treatment and the final disposal (Costa et al., 2012). The concern with the MSW classification has been growing in the BRICS, encouraged through regulations, such as The People's Republic of China's regulation on Prevention of Environmental Pollution Caused by Solid Waste and The Administrative Measures for Urban Living Garbage, as well as The Brazilian National Policy on Solid Waste (Brazil, 2011). It may be noticed that all these regulations establish administrative measures and specific methods for MSW classification.

Regarding the generation of MSW, Campos (2012) states that this is driven by economic and behavioral factors, besides the influence of population factors, which are related to population growth and its concentration in urban areas. Table 2 presents a synthesis of the generation and composition of USW in BRICS countries. It can be observed that there has been an increase in waste production, specifically in China and India, in parallel with rapid urbanization over the last three decades, according to Wang et al. (2016).

According to Sharholy et al. (2008), the per capita generation of MSW ranges from 0.2 to $0.5 \mathrm{~kg} /$ inhabitant/day, in India, and it has annual growth of 1 to $1.33 \%$. Further, in some cities, the generation may be even higher because of the high levels of urbanization standards. Patel et al. (2010) also emphasize that both population and economic growth have influenced significant changes in the quantity and characteristics of waste generated in the last 20 years in the country, making the management waste a problem to be solved through formulation and adoption of appropriate techniques for each type of waste generated.

Zhang et al. (2010) also point out that China has been facing challenges to manage its waste due to the increase in per capita generation, which is around $1.134 \mathrm{~kg} / \mathrm{inhabitant} / \mathrm{day}$. In Brazil, as can be seen in Table 2, the generation is $1.062 \mathrm{~kg} / \mathrm{inhabitant} / \mathrm{day}$ and in Russia 0.63 $\mathrm{kg} / \mathrm{inhabitant/day.} \mathrm{In} \mathrm{the} \mathrm{studied} \mathrm{articles,} \mathrm{there} \mathrm{is} \mathrm{no} \mathrm{information} \mathrm{for} \mathrm{the} \mathrm{per} \mathrm{capita} \mathrm{generation}$ in South Africa. 
Table 2. Generation and composition of USW in BRICS.

\begin{tabular}{lll}
\hline Authors & Countries (Cities under study) & Generation and Composition \\
\hline Couth and Trois (2010); & South Africa (Cape Town and & Generation: 870,000 tons of recyclable material. \\
Snyman and Vorster & Tshwane) & Generation per capita: NI* \\
(2011) & & $\begin{array}{l}\text { Composition: South Africa }-50 \% \text { of USW is organic } \\
\text { (Liebenberg, 2007) }\end{array}$ \\
& & $\begin{array}{l}\text { Projection: Estimation of diminishing fraction of organic } \\
\text { waste to 42.5\% by 2022 in the city of Tshwane }\end{array}$ \\
\hline
\end{tabular}

Lino and Ismail (2013);

Toso and Alem (2014);

Leme et al. (2014);

Rutkowski and

Rutkowski (2015)
Brazil (Campinas, Sorocaba and Generation: 200 tons of USW per day in Betim Betim)

Generation per capita: 1,062 kg/inhabitant/day for Brazil (ABRELPE, 2015)

Composition: Campinas - $46 \%$ organic material, $20 \%$ paper, $15 \%$ plastic, $4 \%$ metal, $2 \%$ glass and $13 \%$ other materials

Sorocaba - of recyclable material, $30.2 \%$ are cardboard, $25.5 \%$ paper, 4.3 tetra pack, $9 \%$ metal, $17.4 \%$ plastic and $12.3 \%$ glass

Projection: NI*
Hui et al. (2006); Song et al. (2013); Jiang et al. (2009); Zhen-Shan et al. (2009); Minghua et al. (2009); Liu and Wu (2010); Liu et al. (2015); Fei et al. (2016); Zhao et al. (2008); Dorn et al. (2012); Wang and Wang (2013); Chen et al. (2010); Dai et al. (2011); Fu et al. (2015)
China (Chongqing, Macao, Lhasa, Shigatse, Nedong District, Bayi District in Nyingchi, Beijing, Shanghai (Pudong), Suzhou, Zhejiang, Guangdong, Hebei, Henan and Sichuan)
Generation: 1,805 million tons of solid waste for domestic urban areas in 2013

Generation per capita: $1.134 \mathrm{~kg} / \mathrm{inh}$ abitant/day for China Composition: Macao $-45.65 \%$ organic material, 16.3 paper, $14.13 \%$ plastic, $5.43 \%$ glass, $3.25 \%$ metal, $2.17 \%$ cloth, $8.7 \%$ wood, and $4.35 \%$ other materials.

Projection: estimated generation of 4,942 tons/day in 2020 in Tibet region

Pattnaik and Reddy
(2010); Sharma et al.
(2010); Patel et al.
(2010); Chattopadhyay
et al. (2009); Kumar et
al. (2009); Sharholy et
al. (2008); Ravindra et
al. (2015); Chakrabarti
et al. (2009); Kumar and
Goel (2009)

Starostina et al. (2014)
India (Pune, Puducherry, Hardwar, Madhya Pradesh, Kolkata, Rajasthan, Uttar Pradesh, Uttarakhand, Deli, Haryana, Punjab, Himachal Pradesh, Jammu, Kashmir, Cashmere and Kharagpur)
Generation: 48 million tons, annual, of USW.

Generation per capita: $0.561 \mathrm{~kg} / \mathrm{inh}$ abitant/day for India Composition: $81.41 \%$ of USW are biodegradable and $18.59 \%$ are not

Projection: Increase to 250 million tons by 2047 (Sharholy et al., 2007)
Russia (Irkutsk)

*Not included.

Thus, in the BRICS countries, despite the fact that they present an increase in waste generation, are still less than the average of $2.2 \mathrm{~kg} /$ inhabitant/day for the OECD (Organisation for Economic Co-operation and Development) (Hoornweg and Bhada-Tata, 2012), which is made up of mainly developed countries. The quantity and composition of the waste reveals consumption and disposal habits of the inhabitants which do not reflect measures implemented to reduce waste generation.

Regarding composition, the largest part of USW generated in South Africa, Brazil, China, India, and Russia is made up of organic material, reflecting consumption patterns of these populations. This scenario can be expected, given that in studies by Singh et al. (2014) and 
Sharholy et al. (2008), in countries considered underdeveloped or developing, there is a growing rate of USW generation and the main contributor is organic material.

Table 3. Storage of USW in BRICS countries.

\begin{tabular}{|c|c|c|}
\hline Authors & Countries (Cities Under Study) & Storage \\
\hline $\begin{array}{l}\text { Jiang et al. (2009); } \\
\text { Minghua et al. (2009); Tai } \\
\text { et al. (2011); Dai et al. } \\
\text { (2011) }\end{array}$ & $\begin{array}{l}\text { China (Lhasa, Shigatse, Nedong } \\
\text { District, Bayi District in Nyingchi, } \\
\text { Beijing, Guangzhou, Shenzhen, } \\
\text { Hangzhou, Nanjing, Xiamen and } \\
\text { Guilin) }\end{array}$ & $\begin{array}{l}\text { Types of Recipients: Containers, } \\
\text { dumpsters and closed locations } \\
\text { Location: Residential and } \\
\text { commercial streets, scheduled } \\
\text { collection points, transfer stations or } \\
\text { stored by USW collection } \\
\text { companies }\end{array}$ \\
\hline $\begin{array}{l}\text { Kumar and Goel (2009); } \\
\text { Pattnaik and Reddy (2010); } \\
\text { Kumar et al. (2009); Zia } \\
\text { and Devadas (2008); } \\
\text { Talyan et al. (2008); } \\
\text { Ravindra et al. (2015) }\end{array}$ & $\begin{array}{l}\text { India (Kharagpur, Puducherry, } \\
\text { Metropolitan Cities, States Capitals, } \\
\text { Deli, States of Rajasthan, Uttar } \\
\text { Pradesh, Uttarakhand, Deli, } \\
\text { Hariyana, Punjab, Himachal } \\
\text { Pradesh, Jammu, Cashmere and } \\
\text { Chandigarh) }\end{array}$ & $\begin{array}{l}\text { Types of recipients: Small trash } \\
\text { recipients at the source, community } \\
\text { containers and concrete deposits } \\
\text { (open and closed) } \\
\text { Location: Open areas and in streets, } \\
\text { without source separation }\end{array}$ \\
\hline Starostina et al. (2014) & Russia (Irkutsk) & $\begin{array}{l}\text { Type of Recipient: Common trash } \\
\text { cans (containers around } 0.75 \mathrm{~m}^{2} \text { ) } \\
\text { Location: Residencies }\end{array}$ \\
\hline
\end{tabular}

\subsection{Storage}

Storage represents an essential procedure for suitable USWM. As one step before collection, the way that solid waste is stored influences how it will be transported. It is recommended that at the points of generation the waste be placed in waste containers selected according to its characteristics; for example, the container must be mechanically and chemically compatible with each waste (Barros, 2012).

Table 3 presents the storage characteristics in China, India and Russia. In the studied articles, no information was found on the remaining BRICS countries.

In China, the use of waste containers, collection points and transfer stations all stand out for temporary storage, in order to aid in transferring USW from small collection vehicles to larger ones. Storage in domestic dumpsters or trash deposits is the method utilized in Russia. In India, the storage is inadequate, generally in open areas and streets, without separation at the source; in certain party of the country, community waste containers are used.

Jiang et al. (2009) and Zia and Devadas (2008) state in their studies on China and India, respectively, that they observed problems in conserving the quality of the public waste containers and the existence of clandestine disposal spots in the storage areas.

\subsection{Collection, Transfer and Transportation}

Collection and transfer of USW must be carried out with suitable frequency in order to avoid excessive accumulation of materials, minimizing risks to the environment and public health. Transportation must be done in adequate vehicles, chosen according to the quantity and type of solid waste being transported, the topographical characteristics and the region's transportation network, as suggested by Rutkowski and Rutkowski (2015).

Analyzing the data presented in Table 4 regarding the way the collection, transfer and transport of USW is carried out in BRICS countries, it can be seen that the collection system adopted is door-to-door in South Africa, Brazil and India, and specific delivery points in Brazil, China, India and Russia. Collection at specific delivery points depends on the population's participation and awareness, given that residents have to go to the locations where the 
dumpsters or containers are placed for waste disposal. In many cases, this does not happen, which creates clandestine deposits.

The collection services in these countries are carried out by public and private companies, which contributes to differences in performance. According to Sharholy et al. (2008), the collection service is more efficient when a third-party is hired for the activity. However, Rajamanikam et al. (2014) detected problems in the city of Puducherry (India) in the execution of services by Non-Governmental Organizations (NGOs) and third-party contractors, who carried out the collection two times per week in order to economize transportation costs. Thus, some regions have low collection frequencies, which lead to overflowing storage locations, which cause uncontrolled burning of urban solid waste around the city.

Table 4. Collection, transfer and transportation of USW in the BRICS countries.

\begin{tabular}{lll}
\hline Authors & $\begin{array}{l}\text { Countries (Cities Under } \\
\text { Study) }\end{array}$ & Collection, Transportation and Transfer \\
\hline Snyman and Vorster & South Africa (Cape Town, & Collection method: Door-to-door \\
(2011); Couth and Trois & Tshwane and Johannesburg) & Utilization of transfer stations: Yes (10 stations in \\
(2010). & & Tshwane). \\
& Form of Transportation: NI* \\
& Responsible: NI* \\
& Frequency: NI* \\
& Efficiency: NI* \\
\hline
\end{tabular}

Rutkowski and Rutkowski Brazil (25 Brazilian Cities) (2015).

Collection method: Door-to-door and/or delivery point. Utilization of transfer stations:

Form of Transportation: Choice made in relation to topography.

Responsible: $\mathrm{NI}^{*}$

Frequency: $\mathrm{NI}^{*}$

Efficiency: Collection efficiency is $90 \%$ (ABRELPE, 2015).

\begin{tabular}{|c|c|c|}
\hline $\begin{array}{l}\text { Hui et al. (2006); Song et al. } \\
\text { (2013); Jiang et al. (2009); } \\
\text { Zhen-Shan et al. (2009); } \\
\text { Dai et al. (2011); Wang } \\
\text { and Wang (2013); Minghua } \\
\text { et al. (2009); Liu et al. } \\
\text { (2015); Wang et al. (2008); } \\
\text { Yang et al. (2015). }\end{array}$ & $\begin{array}{l}\text { China (Chongqing, Macao, } \\
\text { Lhasa, Shigatse, Nedong } \\
\text { District, Bayi District in } \\
\text { Nyingchi, Beijing and } \\
\text { Shanghai) }\end{array}$ & $\begin{array}{l}\text { Collection method: Delivery points } \\
\text { Utilization of transfer stations: Yes } \\
\text { Form of Transportation: Trucks (with and without } \\
\text { compaction) } \\
\text { Responsible: State owned and private companies. } \\
\text { Frequency: NI* } \\
\text { Efficiency: NI* }\end{array}$ \\
\hline $\begin{array}{l}\text { Narayana (2009); Pattnaik } \\
\text { and Reddy (2010); Sharma et } \\
\text { al. (2010); Chattopadhyay et } \\
\text { al. (2009); Kumar et al. } \\
\text { (2009); Sharholy et al. } \\
\text { (2008); Zia and Devadas } \\
\text { (2008); Talyan et al. (2008); } \\
\text { Pandey et al. (2012); } \\
\text { Rajamanikam et al. (2014); } \\
\text { Ravindra et al. (2015); } \\
\text { Chakrabarti et al. (2009); } \\
\text { Kumar and Goel (2009). }\end{array}$ & $\begin{array}{l}\text { India (Puducherry, Hardwar, } \\
\text { Kolkata, Metropolitan Cities, } \\
\text { States Capitals, Kanpur, Delhi, } \\
\text { Bhagalpur and Kharagpur) }\end{array}$ & $\begin{array}{l}\text { Form of Collection: Door-to-door and/or delivery points. } \\
\text { Utilization of Transfer Stations: Yes } \\
\text { Form of Transportation: Trucks (with and without } \\
\text { compaction) } \\
\text { Responsible: State owned and private companies. Street } \\
\text { sweepers and recyclable materials collectors. } \\
\text { Frequency: From Monday to Friday } \\
\text { Efficiency: The efficiency measurement in India is around } \\
60 \text { to } 70 \% \text {. }\end{array}$ \\
\hline Starostina et al. (2014). & Russia (Irkutsk) & $\begin{array}{l}\text { Form of Collection: Delivery points. } \\
\text { Utilization of Transfer Stations: NI* } \\
\text { Form of Transportation: NI* } \\
\text { Responsible: NI* } \\
\text { Frequency: Every day, every-other day or two times per } \\
\text { week, depending on necessity. } \\
\text { Efficiency: NI* }\end{array}$ \\
\hline
\end{tabular}

\footnotetext{
*Not included.
} 
The participation of the informal sector, by means of street sweepers and recyclable material gatherers is a trademark characteristic of the collection system used in Brazil, China and India. In terms of optimizing USW transportation, most studied cities have transfer stations, which help to reduce transportation costs. However, the number of stations is not sufficient, in many cases, mainly in large-scale cities, where studies must be done to optimize routes and locations for containers and dumpsters in order to improve the selective collection.

\subsubsection{Selective Collection}

The activity of selective collection feeds the cycle of reuse, recycling and composting. It is through this process that recyclable materials are sorted from non-recyclable and organic material. Organic material will be destined for composting. Table 5 presents the synthesis of selective collection in BRICS.

Toso and Alem (2014) highlight the difference between Brazil and the other countries, mainly in the way that USW is separated for recycling. Other countries sort them by type (paper, cardboard, etc.), while in Brazil they are broken into sub-groups of recyclable materials (and, obviously, non-recyclables).

In Brazil, the selective collection activity is done mainly through door-to-door and Voluntary Delivery Points (VDP), carried out by public authorities and, in some cases, partnership with the informal sector. The inclusion of the informal sector through associations and cooperatives has been increasingly incentivized throughout the country, since the approval of the National Solid Waste Policy (Brazil, 2010). However, according to Ferri et al. (2015), a great challenge resides in the task of integration of the recyclable material gatherers and the overall USWM system, often due to their lack of capacity to carry out this activity, which is essential mainly to deal with the health and safety aspects of these workers in the operation of associations and cooperatives.

In China and India, according to Sharholy et al. (2008), the task is predominantly done by the informal sector; the role of the government in recovering these materials is small. The presence of the informal sector in these countries does not occur in a planned fashion, but rather as a result of economic conditions seen by the population. In China, for example, the informal workers organization was always a challenge for the Chinese government, bringing social problems (Wang et al., 2008 e Liu et al., 2015). Liu et al. (2015) also emphasize that one way to solve this social issue would be to employ informal waste pickers in recycling companies.

Table 5. USW Treatment in BRICS countries.

\begin{tabular}{|c|c|c|}
\hline Authors & Countries (Cities under study) & Treatment \\
\hline $\begin{array}{l}\text { Snyman and Vorster (2011); Couth } \\
\text { and Trois (2010). }\end{array}$ & $\begin{array}{l}\text { South Africa (Cape Town, Tshwane } \\
\text { and Johannesburg) }\end{array}$ & $\begin{array}{l}\text { Type of treatment: Composting for urban solid waste. } \\
\text { (Coetzee et al., 2007) }\end{array}$ \\
\hline Rutkowski and Rutkowski (2015). & Brazil (25 Brazilian Cities) & $\begin{array}{l}\text { Type of treatment: recycling and of reuse of urban solid } \\
\text { waste. }\end{array}$ \\
\hline $\begin{array}{l}\text { Song et al. (2013); Jiang et al. } \\
\text { (2009); Zhen-Shan et al. (2009); } \\
\text { Minghua et al. (2009); Liu et al. } \\
\text { (2015); Tai et al. (2011); Dorn et al. } \\
\text { (2012); Chen et al. (2010); Dai et } \\
\text { al. (2011); Wang and Wang } \\
\text { (2013); Zhao et al. (2008). }\end{array}$ & $\begin{array}{l}\text { China (Macao, Lhasa, Shigatse, } \\
\text { Nedong Lhoka District, Bayi District } \\
\text { in Nyingchi, Beijing, Shanghai, } \\
\text { Guangzhou, Shenzhen, Hangzhou, } \\
\text { Nanjing, Xiamen and Guilin) }\end{array}$ & Type of treatment: incineration, compost and recycling. \\
\hline $\begin{array}{l}\text { Narayana (2009); Jha et al. (2008); } \\
\text { Chattopadhyay et al. (2009); Kumar } \\
\text { et al. (2009); Zia and Devadas } \\
\text { (2008); Sharholy et al. (2008); } \\
\text { Rajamanikam et al. (2014); } \\
\text { Chakrabarti et al. (2009); Kumar } \\
\text { and Goel (2009). }\end{array}$ & $\begin{array}{l}\text { India (Delhi, Mumbai, Calcutta, } \\
\text { Chennai, Metropolitan Cities, State } \\
\text { Capitals, Kanpur, Puducherry and } \\
\text { Kharagpur) }\end{array}$ & $\begin{array}{l}\text { Type of treatment: } 47 \% \text { of USW generated were recovered } \\
\text { through active recycling and composting practices in the area } \\
\text { of Raj Bhavan and Puducherry. }\end{array}$ \\
\hline Starostina et al. (2014). & Russia (Irkutsk) & Type of Treatment: Only $3 \%$ of USW are recycled in the city. \\
\hline
\end{tabular}




\subsection{Treatment}

Inadequate management of USW in terms of treatment results in economic losses and poses a threat to public health and natural resources (Abduli et al., 2013). Zhang et al. (2010) affirm that any activity for USW treatment not only diminishes the total amount of waste generated but also the costs of disposal. Even with these clear gains through treatment, all the studied articles highlight treatment activities as hurdles to be overcome in BRICS countries. Table 6 presents the types of treatments which already exist.

The articles about South Africa, China and India affirm the existence of composting. However, some problems are identified, such as low quality and lack of market for the composted product. Based on the fact that USW in BRICS countries have a large portion of organic material, composting should be considered in these locations. Some authors, such as Abduli et al. (2013), Zhang et al. (2010) and Sharholy et al. (2008), suggest that composting needs to be improved, which is essential to the implementation of the separation of waste material from the generating source so that recyclable materials can be routed to recycling processes and organic material to composting.

Incineration, on the other hand, is a common practice in large cities in China. In small cities, USW presents a low heat-generating power, as pointed out by Chen et al. (2010). However, incineration has been increasing due to subsidies from the Chinese government and private investments aimed at reducing the volume of USW and the generation of energy. In India, Narayana (2009) affirms that this activity has not been so common due to high humidity levels, low heat-generating content and reduced volumes, which will not meet the needs of central incineration installations. In Brazil, treatment by incineration is in a secondary context (Brazil, 2010). Incinerators within the country are used mainly to process waste considered as needing special treatment, such as health-service waste.

Related to recycling, the informal sector has a strong participation in the BRICS countries. Wang et al. (2008) point out that recyclable material gatherers sustain the entire recycling system in developing countries. Therefore, there is a need to formally integrate these important members of the system, considering that many times these workers suffer from government negligence and need professional training and legalized work. Among these countries, Brazil stands out as a reference in social inclusion for recyclable material gatherers through cooperatives and associations (Ezeah et al., 2013).

Table 6. Selective Collection in BRICS countries.

\begin{tabular}{|c|c|c|}
\hline Authors & Countries (Cities under study) & Selective Collection \\
\hline Couth and Trois (2010) & $\begin{array}{l}\text { South Africa (Cape Town and } \\
\text { Johannesburg) }\end{array}$ & $\begin{array}{l}\text { Type of collection: } \mathrm{NI}^{*} \\
\text { Separation: Dry and wet waste materials } \\
\text { Responsible: NI* }\end{array}$ \\
\hline $\begin{array}{l}\text { Lino and Ismail (2013); Toso } \\
\text { and Alem (2014); Ferri et al. } \\
\text { (2015); Rutkowski and } \\
\text { Rutkowski (2015) }\end{array}$ & $\begin{array}{l}\text { Brazil (Campinas, Sorocaba and } \\
\text { others } 25 \text { Brazilian Cities) }\end{array}$ & $\begin{array}{l}\text { Type of collection: Door-to-door and VDP } \\
\text { Separation: Recyclable Wastes are collected and then sorted. } \\
\text { Responsible: Public authorities, private companies, associations } \\
\text { and cooperatives. }\end{array}$ \\
\hline $\begin{array}{l}\text { Hui et al. (2006); Liu et al. } \\
\text { (2015); Fei et al. (2016); Xu et } \\
\text { al. (2015); Wang et al. (2008) }\end{array}$ & $\begin{array}{l}\text { China (Chongqing, Beijing, Suzhou } \\
\text { and Haidian (Beijing District)) }\end{array}$ & $\begin{array}{l}\text { Type of collection: } \mathrm{NI}^{*} \\
\text { Separation: Separated in trash cans, streets and/or locations for } \\
\text { final disposal. } \\
\text { Responsible: Informal sector - by gatherers and informal } \\
\text { buyers of recyclable materials. }\end{array}$ \\
\hline $\begin{array}{l}\text { Zia and Devadas (2008); } \\
\text { Rajamanikam et al. (2014) }\end{array}$ & $\begin{array}{l}\text { India (Kanpur, State of Rajasthan, } \\
\text { Uttar Pradesh, Uttarakhand, Delhi, } \\
\text { Haryana, Punjab, Himachal } \\
\text { Pradesh, Jammu, Cashmere and } \\
\text { Puducherry) }\end{array}$ & $\begin{array}{l}\text { Type of collection: Inhabitants sell them in recycling areas. } \\
\text { Separation: Dry and wet waste materials. } \\
\text { Responsible: Informal sector. }\end{array}$ \\
\hline Starostina et al. (2014) & Russia (Irkutsk) & $\begin{array}{l}\text { Type of collection: Paper and glass are commercialized on the } \\
\text { market. } \\
\text { Separation: NI* Responsible: NI* }\end{array}$ \\
\hline
\end{tabular}

*Not included. 


\subsection{Final Disposal}

Final disposal of USW consists of the adoption of procedures which aim to release the waste into the ground, minimizing environmental impacts by following operational norms to avoid public health problems and promote population safety. In Brazil, final disposal is restricted to USW which cannot be treated or recovered, classified as rejected (Brazil, 2010).

In this sense, the study showed the strong presence of landfills in the investigated countries (Table 7), which many times are irregular, or do not present a collection system, nor leachate or gas/drainage treatment system (with or without energy generation). Urban Solid Waste is also disposed of in open-air environments without any concern for the environment, which can cause public health problems.

Table 7. Final disposal in BRICS countries.

\begin{tabular}{|c|c|c|}
\hline Authors & Countries (Cities under study) & Final Disposition \\
\hline Snyman and Vorster (2011). & South Africa (Tshwane) & $\begin{array}{l}\text { Type of final disposal: } \\
\text { Landfills }\end{array}$ \\
\hline $\begin{array}{l}\text { Lino and Ismail (2013); Toso and Alem } \\
\text { (2014); Leme et al. (2014); Rutkowski } \\
\text { and Rutkowski (2015). }\end{array}$ & $\begin{array}{l}\text { Brazil (Campinas, Sorocaba, } \\
\text { Betim and others } 25 \text { Brazilian } \\
\text { Cities) }\end{array}$ & $\begin{array}{l}\text { Type of final disposal: open } \\
\text { dump (open-air, without } \\
\text { treatment), controlled landfills }\end{array}$ \\
\hline $\begin{array}{l}\text { Song et al. (2013); Jiang et al. (2009); } \\
\text { Zhen-Shan et al. (2009); Minghua et al. } \\
\text { (2009); Liu et al. (2015); Tai et al. } \\
\text { (2011); Chen et al. (2010); Dai et al. } \\
\text { (2011); Wang and Wang (2013). }\end{array}$ & $\begin{array}{l}\text { China (Macao, Lhasa, Shigatse, } \\
\text { Nedong Lhoka District, Bayi } \\
\text { Nyingtri District, Beijing, } \\
\text { Shanghai, Guangzhou, } \\
\text { Shenzhen, Hangzhou, Nanjing, } \\
\text { Xiamen and Guilin) }\end{array}$ & $\begin{array}{l}\text { Type of final disposal: } \\
\text { Landfills and dumps }\end{array}$ \\
\hline $\begin{array}{l}\text { Narayana (2009); Jha et al. (2008); } \\
\text { Pattnaik and Reddy (2010); } \\
\text { Chattopadhyay et al. (2009); Kumar et } \\
\text { al. (2009); Zia and Devadas (2008); } \\
\text { Talyan et al. (2008); Hazra and Goel } \\
\text { (2009); Pandey et al. (2012); Ravindra } \\
\text { et al. (2015); Chakrabarti et al. (2009); } \\
\text { Kumar and Goel (2009); Sharma et al. } \\
(2010) \text {. }\end{array}$ & $\begin{array}{l}\text { India (Delhi, Mumbai, Calcutta, } \\
\text { Chennai, Puducherry, Kolkata, } \\
\text { Metropolitan Cities, States } \\
\text { Capitals, Kanpur, Bhagalpur, } \\
\text { State of Rajasthan, Uttar } \\
\text { Pradesh, Uttarakhand, Haryana, } \\
\text { Punjab, Himachal Pradesh, } \\
\text { Jammu, Cashmere, Chandigarh, } \\
\text { Kharagpur and Haridwar) }\end{array}$ & $\begin{array}{l}\text { Type of final disposal: } \\
\text { uncontrolled landfills, dumps } \\
\text { and clandestine dumping sites } \\
\text { (highways and empty lots) }\end{array}$ \\
\hline Starostina et al. (2014). & Russia (Irkutsk) & $\begin{array}{l}\text { Type of disposal: } 500,000 \text { tons } \\
\text { of USW deposited, per year, in } \\
\text { the landfills. }\end{array}$ \\
\hline
\end{tabular}

In Brazil in 2014, dumps represented $28 \%$ of the final destination per municipality; controlled landfills were $32 \%$ and sanitary landfills, 40\% (ABRELPE, 2015). In India, according to Narayana (2009), 90\% of generated waste is deposited in open places. The limitation of space for landfills, due to dramatic urban growth and scarcity of resources, has hindered the construction of safe, controlled landfills in Indian cities (Chakrabarti et al., 2009).

It was observed that most of the BRICS countries do not have adequate waste management systems. Wastes with high pollution potential, which should have special disposal treatment, are erroneously sent to domestic waste landfills. According to studies by Snyman and Vorster (2011), in South Africa, for example, $50 \%$ of domestic waste, $28 \%$ of green waste, $14 \%$ of civil construction waste, and $8 \%$ of industrial waste are deposited in the Tshwane landfill. 


\section{FINDINGS}

The BRICS countries face constraints in the USWM that can be solved, but this requires the more active participation of the population, the government and the private sector, as Narayana (2009) argues. In this way, it was possible to observe these points of improvement and good practices in the five countries studied from the USWM status study. The positive initiatives can be reproduced with modifications that respect characteristics, dimensions, generation of waste, population and individualities of each country.

The centralization of the USWM services in public agencies, in the BRICS countries, was observed in the articles studied. Thus, in order to ensure the participation of all sectors, incentives are recommended for the decentralization of the management stages from the definition of responsibilities between private initiative, public authority and population. Chen et al. (2010) emphasize that an integrated approach to the services offered by the system is necessary, considering the roles of these three stakeholders.

Focusing on the MSW generation stage, China shows that an absence of a volume limit of MSW generated is a real gap during all the generation process (Zhang et al, 2010); consequently, more investments are required for the final disposal of the waste. The authors themselves suggest the implementation of a charge for waste generation. In this way it would be possible to recover USWM costs and increase financial support for waste disposal facilities.

The analyzed articles pointed to some faults in the storage and collection of MSW in India, where some municipalities have community containers with excessive waste, clandestine disposal sites and poor conservation of the waste containers. The article by Rajamanikam et al. (2014) concludes that the cause of high MSW stocking in community waste containers in India is due to the low frequency of waste collection in the municipality of Puducherry. As a good practice of collection and storage, the article by Starostina et al. (2014) states that in the city of Irkutsk (Russia) the waste is stored in individual waste containers for each household; these containers are emptied frequently (every day, every two days or twice a week). Consequently, there is a decrease in USW accumulation and also in waste-burning, as reported by Rajamanikam et al. (2014). In this way, it is suggested that collection frequency should be designed to take into account the amount of waste generated and the waste containers' storage capacity, as in the Irkutsk city.

Regarding waste treatment, composting is the most viable treatment form, due to the great proportion of organic material present in the overall breakdown of USW in BRICS countries, as indicated by Zia and Devadas (2008), Kumar et al. (2009) and Narayana (2009). However, to initiate this activity, the material must be separated at the generating source in order that the recyclable material can be directed to recycling, and organic material to composting. An example of good management practice is the Sao Paulo Project (Sao Paulo, 2014), which is connected to the Sao Paulo city government and aims to orient and reduce the waste of tons of organic waste. This organic waste is not reused but is sent without treatment to the city sanitary landfills. Therefore, it is important to emphasize that the treatment choice will also be influenced by political, social, economic and environmental factors, such as political interests, financial resources availability and environmental awareness.

The main form of final disposal in BRICS countries is sanitary landfills, which are frequently found to be in irregular and/or clandestine operation. Practices of reduction of generation, separation at the source, recycling and composting are all important tools to diminish the volume of USW destined for landfills, and, in turn, encourage only rejected material to be sent to these deposits. This reduction in the waste volume sent to final disposal is extremely important to increase the landfills lifespan and to reduce both new disposal areas and investments. 
Thus, in the case of future directions for USWM, benchmarking the use of the best management practices in countries and municipalities is fundamental. Moreover, engagement and discipline of the three sectors (population, public and private authorities) in the USWM are meaningful characteristics to increase performance and efficiency in the stages of management.

\section{CONCLUSIONS}

The objective of this article was to analyze the status of urban solid waste management in BRICS countries through a Systematic Literature Review. Essential points were taken into account in the USWM, such as the generation rate, composition, storage form, collection, besides the main ways of treatments and final disposal of MSW. This initial stage of research and data collection sought to information and knowledge about the techniques, strategies and methods used in these countries. From the results and discussions about the analysis of the 46 articles selected for this work, it was possible to make some recommendations, contributing in this way to better waste management in these countries.

The BRICS countries present a lot of common characteristics, such as problems in their management systems, the participation of the informal sector, considerable quantities of organic material, the use of landfills and irregular areas for final disposal.

The main barriers to USWM faced by these countries are directly related to a lack of financial resources, adequate local infrastructure, planning, quantity data, types of waste generated and definition of responsibilities of the agents involved in the process. The implementation of long-term planning measures that encourage the reduction of generation, separation at source, recycling, composting and landfill volume reduction are some actions that can be taken by these countries to improve the USWM system.

It is important to highlight the meaningful role of the informal sector in the collection and separation stages of MSW in BRICS countries. However, it is evident that the informal sector is not integrated into the formal management system and this integration is necessary to increase the efficiency of USWM. Regarding the integration process, this can occur through professional training, as well as through the legalization of the work of these waste pickers, which lead to an increase in the amount of recyclable waste collected and, consequently, facilitate treatment and final disposal stages. In this sense, economic, environmental and social gains are generated.

The decentralization of USWM services, along with definitions of clear roles and responsibilities for the public and private sectors, in cooperation with the population, is noted as a necessary measure for the creation of efficient USWM in BRICS countries. This decentralization can favor the management system as it begins to consider the typical features of each locality throughout management system planning. Inadequate MSW management, in terms of treatment technologies, recycling, final disposal and management strategy, leads to economic loss while posing a threat to public health and natural resources.

It is worth mentioning that there is no single model for USWM which would meet the needs of all countries. Each solution must be based on location, taking into account not only the physical characteristics of the system, but also the governmental and cultural factors. Although, regardless of the location, for the management to guarantee a minimum level of satisfaction there must be both administrative (public policies, legislation, financial and human resources) and technical-operational (storage, collection, transportation, treatment and final disposal) structures in place.

Furthermore, before any USWM implementation, municipalities must put themselves through multiple assessments in terms of technology and possible methods to be used. Thus, studies which identify local characteristics and necessities must be elaborated. The system must be structured to attend the local reality through suitable regulations, contributing to sustainable 
management of urban solid waste and seeking to work in conjunction with the public sector, the private sector and society, all with well-defined roles and responsibilities.

\section{ACKNOWLEDGEMENTS}

The authors would like to thank CAPES, CNPq, and FAPEMIG for their financial support given to many projects that helped develop this study.

\section{REFERENCES}

ABDULI, M. A.; TAVAKOLLI, H.; AZARI, A. Alternatives for solid waste management in Isfahan, Iran a case study. Waste Management \& Research, v. 31, n. 5, p. 532-537, 2013. https://doi.org/10.1177/0734242X13477718

ALLESCH, A.; BRUNNER, P. H. Assessment methods for solid waste management: A literature review. Waste Management \& Research, v. 32, n. 6, p. 461-473, 2014. http://doi.org/10.1177/0734242X14535653

BATOOL, S. A.; CHAUDHRY, N.; MAJEED, K. Economic potential of recycling business in Lahore, Pakistan. Waste Management, v. 28, p. 294-298, 2008. https://doi.org/10.1016/j.wasman.2006.12.007

BARROS, R. M. Solid Waste Treaty: management, use, and sustainability. Rio de Janeiro: Interciência, 2012. $374 \mathrm{p}$.

BIOLCHINI, J. C. A.; MIAN, P. G.; NATALI, A. C. C.; CONTE, T. U.; TRAVASSOS, G. H. Scientific research ontology to support systematic review in software engineering. Advanced Engineering Informatics, v. 21, p. 133-151, 2007.

BRAZIL. Lei $\mathrm{N}^{\circ}$ 12.305, de 2 de agosto de 2010. Institui a Política Nacional de Resíduos Sólidos; altera a Lei no 9.605, de 12 de fevereiro de 1998; e dá outras providências. Diário Oficial [da] União, Brasília, 3 ago. 2010.

BRAZIL. Ministry of Foreign Affairs. Economic Data and Trade Statistics. 2014. Available in: http://brics.itamaraty.gov.br/pt_br/sobre-o-brics/dados-economicos. Access in: November 02, 2016.

BRAZIL Ministry of Environment. National Policy of Solid Waste. 2011. Available in: http://www.mma.gov.br/pol\%C3\%ADtica-de-res\%C3\%ADduos-s\%C3\%B3lidos. Access in: March 02, 2017.

BRAZILIAN PUBLIC CLEANERS COMPANIES AND SPECIAL WASTE ASSOCIATION - ABRELPE. Overview of Solid Waste in Brazil 2014. São Paulo, 2015. 118 p.

BRERETON, P.; KITCHENHAM, B. A.; BUDGEN, D.; TURNER, M.; KHALIL, M. Lessons from applying the systematic literature review process within the software engineering domain. The Journal of System and Software, v. 80, p. 571-583, 2007. https://doi.org/10.1016/j.jss.2006.07.009

CAMPOS, H. K. T. Income and evolution of per capita generation of solid waste in Brazil. Engenharia Sanitária e Ambiental, v. 17, n. 2, p. 171-180, 2012. http://dx.doi.org/10.1590/S1413-41522012000200006

CHAKRABARTI, S.; MAJUMDER, A.; CHAKRABARTI, S. Public-community participation in household waste management in India: An operational approach. Habitat International, v. 33, p. 125-130, 2009. https://doi.org/10.1016/j.habitatint.2008.05.009 
CHATTOPADHYAY, S.; DUTTA, A.; RAY, S. Municipal solid waste management in Kolkata, India - A review. Waste Management, v. 29, p. 1449-1458, 2009. https://doi.org/10.1016/j.wasman.2008.08.030

CHEN, C. A performance evaluation of MSW management practice in Taiwan. Resources, $\begin{array}{llllll}\text { Conservation and Recycling, v. 54, p. 1353-1361, } 2010 . & \end{array}$ https://doi.org/10.1016/j.resconrec.2010.05.003

CHEN, X.; GENG, Y.; FUJITA, T. An overview of municipal solid waste management in $\begin{array}{llllll}\text { China. Waste } & \text { Management, } & \text { v. 30, }\end{array}$ https://doi.org/10.1016/j.wasman.2009.10.011

COETZEE, J. A.; HAIDER, M. S.; HALL, C. J.; KERAAN, S. Impacts on solid waste disposal resulting from the implementation of integrated waste management policies and plans: City of Cape Town, South Africa, 2007. In: INTERNATIONAL WASTE MANAGEMENT AND LANDFILL SYMPOSIUM, 17., 2007, Santa Margherita di Pula, Cagliari, Proceedings... Sardinia, out. 2007.

COOK, D. J.; MULROW, C. D.; HAYNES, R. B. Systematic Reviews: Synthesis of Best Evidence for Clinical Decisions. Annals of Internal Medicine, v. 126, p. 376-380, 1997.

COSTA, L. E. B.; COSTA, S. K.; REGO, N. A. C.; SILVA JUNIOR, M. F. Gravimetric model of household solid waste and socio-economic profile in the city of Salinas / MG. Revista Ibero - Americana de Ciências Ambientais, v. 3, n. 2, p. 73-90, 2012. https://doi.org/10.6008/ESS2179-6858.2012.002.0005

COUTH, R.; TROIS, C. Carbon emissions reduction strategies in Africa from improved waste management: A review. Waste Management, v. 30, p. 2336-2346, 2010. https://doi.org/10.1016/j.wasman.2010.04.013

DAI, C.; LI, Y. P.; HUANG, G. H. A two-stage support-vector-regression optimization model for municipal solid waste management e a case study of Beijing, China. Journal of Environmental Management, v. 92, p. 3023-3037, 2011. https://doi.org/10.1016/j.jenvman.2011.06.038

DAMGHANI, A. M.; SAVARYPOUR, G.; ZAND, E.; DEIHIMFARD, R. Municipal solid waste management in Tehran: current practices, opportunities and challenges. Waste Management, v. 28, p. 929-934, 2008. https://doi.org/10.1016/j.wasman.2007.06.010

DORN, T.; NELLES, M.; FLAMME, S.; JINMING; C. Waste disposal technology transfer matching requirement clusters for waste disposal facilities in China. Waste Management, v. 32, p. 2177-2184, 2012. https://doi.org/10.1016/j.wasman.2012.05.038

EZEAH, C.; FAZAKERLEY, J. A; ROBERTS, C. L. Emerging trends in informal sector recycling in developing and transitional countries. Waste Management, v. 33, p. 25092519, 2013. https://doi.org/10.1016/j.wasman.2013.06.020

FEI, F.; QU, L.; WEN, Z.; XUE, Y.; ZHANG, H. How to integrate the informal recycling system into municipal solid waste management in developing countries: Based on a China's case in Suzhou urban area. Resources, Conservation and Recycling, v. 110, p. 74-86, 2016. https://doi.org/10.1016/j.resconrec.2016.03.019

FERRI, G. L.; CHAVES, G. L. D.; RIBEIRO, G. M. Reverse logistics network for municipal solid waste management: The inclusion of waste pickers as a Brazilian legal requirement. $\begin{array}{llllll}\text { Waste } & \text { Management, } & \text { v. } & 4015 .\end{array}$ https://doi.org/10.1016/j.wasman.2015.02.036 
FU, H.; LI, Z.; WANG, R. Estimating municipal solid waste generation by different activities and various resident groups in five provinces of China. Waste Management, v. 41, p. 311, 2015. https://doi.org/10.1016/j.wasman.2015.03.029

HAZRA, T.; GOEL, S. Solid waste management in Kolkata, India: Practices and challenges. $\begin{array}{llllll}\text { Waste } & \text { Management, } & \text { v. 29, } & \text { p. }\end{array}$ https://doi.org/10.1016/j.wasman.2008.01.023

HOORNWEG, D.; BHADA-TATA, P. What a waste: a global review of solid waste management. Washington, DC: World Bank, 2012.

HUI, Y.; LI'AO, W.; FENWEI, S.; GANG, H. Urban solid waste management in Chongqing: Challenges and opportunities. Waste Management, v. 26, p. 1052-1062, 2006. https://doi.org/10.1016/j.wasman.2005.09.005

IRKUTSK. Ministry of Natural Resources and Environment - MNREIR. About a situation and protection of the environment in Irkutsk region: year 2011. Irkutsk, 2012.

IRKUTSK. Municipal Ordinance of Irkutsk - MOI. The adoption of the norms of an annual municipal waste generation in the city of Irkutsk. Irkutsk, 2008.

JHA, A. K.; SHARMA, C.; SINGH, N.; RAMESH, R.; PURVAJA, R.; GUPTA, P. K. Greenhouse gas emissions from municipal solid waste management in Indian mega-cities: A case study of Chennai landfill sites. Chemosphere, v. 71, p. 750-758, 2008. https://doi.org/10.1016/j.chemosphere.2007.10.024

JIANG, J.; LOU, Z.; NG, S.; LUOBU, C.; JI, D. The current municipal solid waste management situation in Tibet. Waste Management, v. 29, p. 1186-1191, 2009. https://doi.org/10.1016/j.wasman.2008.06.044

JIN, J.; WANG, Z.; RAN, S. Solid waste management in Macao: practices and challenges. $\begin{array}{llllll}\text { Waste } & \text { Management, } & \mathbf{v} & 2606, & \end{array}$ https://doi.org/10.1016/j.wasman.2005.08.006

KUMAR, K. N.; GOEL, S. Characterization of Municipal Solid Waste (MSW) and a proposed management plan for Kharagpur, West Bengal, India. Resources, Conservation and Recycling, v. 53, p. 166-174, 2009. https://doi.org/10.1016/j.resconrec.2008.11.004

KUMAR, S.; BHATTACHARYYA, J. K.; VAIDYA, A. N.; CHAKRABARTI, T.; DEVOTTA, S.; AKOLKAR, A. B. Assessment of the status of municipal solid waste management in metro cities, state capitals, class I cities, and class II towns in India: An $\begin{array}{llllll}\text { insight. Waste Management, } & \text { v. 29, p. 883-895, }\end{array}$ https://doi.org/10.1016/j.wasman.2008.04.011

LEME, M. M. V.; ROCHA, M. H.; LORA, E. E. S.; VENTURINI, O. J.; LOPES, B. M.; FERREIRA, C. H. Techno-economic analysis and environmental impact assessment of energy recovery from Municipal Solid Waste (MSW) in Brazil. Resources, $\begin{array}{lllllll}\text { Conservation and Recycling, } & \text { v. 87, } & \text { p. } & \text { 8-20, }\end{array}$ https://doi.org/10.1016/j.resconrec.2014.03.003

LIEBENBERG, C. J. Public Private Partnership solutions to waste management in developing countries in Africa, 2007. In: INTERNATIONAL WASTE MANAGEMENT AND LANDFILL SYMPOSIUM, 17., 2007. Santa Margherita di Pula, Cagliari. Proceedings... Sardinia, out. 2007. 
LINO, F. A. M.; ISMAIL, K. A. R. Alternative treatments for the municipal solid waste and domestic sewage in Campinas, Brazil. Resources, Conservation and Recycling, v. 81, p. 24-30, 2013. https://doi.org/10.1016/j.resconrec.2013.09.007

LINZNER, R.; SALHOFER, S. Municipal solid waste recycling and the significance of informal sector in urban China. Waste Management \& Research, v. 32, n. 9, p. 896907, 2014. https://doi.org/10.1177/0734242X14543555

LIU, C.; WU, X. Factors influencing municipal solid waste generation in China: A multiple statistical analysis study. Waste Management \& Research, v. 29, p. 371-378, 2010. http://doi.org/10.1177/0734242X10380114

LIU, T.; WU, Y.; TIAN, X.; GONG, Y. Urban household solid waste generation and collection in Beijing, China. Resources, Conservation and Recycling, v. 104, p. 31-37, 2015. https://doi.org/10.1016/j.resconrec.2015.09.004

LOUREIRO, S.; ROVERE, E.; MAHLER, C. Analysis of Potential for Reducing Emissions of Greenhouse Gases in Municipal Solid Waste in Brazil, in the State and City of Rio de Janeiro. Waste Management, v. 33, p. 1302-1312, 2013. https://doi.org/10.1016/j.wasman.2013.01.024

MASSOD, M.; BARLOW, C. Y.; WILSON, D. C. An assessment of the current municipal solid waste management system in Lahore, Pakistan. Waste Management \& Research, v. 32, n. 9, 2014. http://doi.org/10.1177/0734242X14545373

MINGHUA, Z.; XIUMIN, F.; ROVETTA, A.; QICHANG, H.; VICENTINI, F.; BINGKAI, L. et al. Municipal solid waste management in Pudong New Area, China. Waste Management, v. 29, p. 1227-1233, 2009. https://doi.org/10.1016/j.wasman.2008.07.016

NARAYANA, T. Municipal solid waste management in India: From waste disposal to recovery of resources? Waste Management, v. 29, p. 1163-1166, 2009. https://doi.org/10.1016/j.wasman.2008.06.038

PANDEY, P. C.; SHARMA, L. K.; NATHAWAT, M. S. Geospatial strategy for sustainable management of municipal solid waste for growing urban environment. Environmental Monitoring and Assessment, v. 184, p. 2419-2431, 2012. https://doi.org/10.1007/s10661-011-2127-2

PATEL M. L.; JAIN, R.; SAXENA, A. Assessment of the Municipal Solid Waste \& Status of Implementation of Municipal Solid Waste (Management \& Handling), Rules, 2000 in the State of Madhya Pradesh, 2008 - A case study. Waste Management \& Research, v. 29, p. 558-562, 2010. https://doi.org/10.1177/0734242X10372662

PATTNAIK, S.; REDDY, M. V. Assessment of Municipal Solid Waste management in Puducherry (Pondicherry), India. Resources, Conservation and Recycling, v. 54, p. 512-520, 2010. https://doi.org/10.1016/j.resconrec.2009.10.008

RADA, E. C.; RAGAZZI, M.; FREDIZZI, P. Web-GIS oriented system viability for municipal solid waste selective collection optimization in developed and transient economies. $\begin{array}{llllll}\text { Waste Management, } & \text { v. 33, } 013 .\end{array}$ https://doi.org/10.1016/j.wasman.2013.01.002 
RAJAMANIKAM, R.; POYYAMOLI, G.; KUMAR, S. R. L. The role of non-governmental organizations in residential solid waste management: A case study of Puducherry, a coastal city of India. Waste Management \& Research, v. 32, p. 867-881, 2014. https://doi.org/10.1177/0734242X14544353

RAVINDRA, K.; KAUR, K.; MOR, S. System analysis of municipal solid waste management in Chandigarh and minimization practices for cleaner emissions. Journal of Cleaner Production, v. 89, p. 251-256, 2015. https://doi.org/10.1016/j.jclepro.2014.10.036

RUTKOWSKI, J. E.; RUTKOWSKI, E. W. Expanding worldwide urban solid waste recycling: The Brazilian social technology in waste pickers inclusion. Waste Management \& Research, v. 33, p. 1084-1093, 2015. https://doi.org/10.1177/0734242X15607424

SANTIAGO, L. S.; DIAS, S. M. F. Sustainability indicators matrix for the management of solid urban waste. Engenharia Sanitária Ambiental, v.17 n.2, p. 203-212, 2012.

SÃO PAUlO (City). Composta São Paulo 2014. 2014. Available in: https://compostasaopaulo.moradadafloresta.eco.br/resultados2014/\#home/0. Aaccess in: March 01, 2017.

SHARHOLY, M.; AHMAD, K.; MAHMOOD, G.; TRIVEDI, R. C. Municipal solid waste management in Indian cities - A review. Waste Management, v. 28, p. 459-467, 2008. https://doi.org/10.1016/j.wasman.2007.02.008

SHARHOLY, M.; AHMAD, K.; VAISHYA, R. C.; GUPTA, R. D. Municipal solid waste characteristics and management in Allahabad, India. Waste Management, v. 27, p. 490496, 2007. https://doi.org/10.1016/j.wasman.2006.03.001

SHARMA, V.; SAINI, P.; GANGWAR, R. S.; JOSHI, B. D. Assessment of municipal solid waste generation and its management in the holy city of Haridwar, Uttarakhand State, India. Waste Management, v. 30, n. 4, p. 725-728, 2010. https://doi.org/10.1016/j.wasman.2010.01.001

SINGH, J.; LAURENTI, R.; SINHA, R.; FROSTELL, B. Progress and challenges to the global waste management system. Waste management \& Research, v. 32, n. 9, p. 800-812, 2014. https://doi.org/10.1177/0734242X14537868

SNYMAN, J.; VORSTER, K. Sustainability of composting as an alternative waste management option for developing countries: a case study of the City of Tshwane. Waste $\begin{array}{lllllll}\text { Management } \quad \text { \& } & \text { Research, } & \text { v. 29, }\end{array}$ https://doi.org/10.1177/0734242X10385747

SONG, Q.; WANG, Z.; LI, J. Environmental performance of municipal solid waste strategies based on LCA method: a case study of Macau. Journal of Cleaner Production, v. 57, p. 92-100, 2013. https://doi.org/10.1016/j.jclepro.2013.04.042

STAROSTINA, V.; DAMGAARD, A.; RECHBERGER, H.; CHRISTENSEN, T. H. Waste management in the Irkutsk Region, Siberia, Russia: Environmental assessment of current practice focusing on landfilling. Waste Management \& Research, v. 32, p. 389-396, 2014. https://doi.org/10.1177/0734242X14526633

SUN, Y.; GRIMES, S. The emerging dynamic structure of national innovation studies: a bibliometric analysis. Scientometrics, v. 106, p. 17-40, 2016. http://doi.org/10.1007/s11192-015-1778-0 
TAI, J.; ZHANG, W.; CHE, Y.; FENG, D. Municipal solid waste source-separated collection in China: A comparative analysis. Waste Management, v. 31, p. 1673-1682, 2011. https://doi.org/10.1016/j.wasman.2011.03.014

TALYAN, V.; DAHIYA, R. P.; SREEKRISHNAN; T. R. State of municipal solid waste management in Delhi, the capital of India. Waste Management, v. 28, p. 1276-1287, 2008. https://doi.org/10.1016/j.wasman.2007.05.017

TOSO, E. A. V.; ALEM, D. Effective location models for sorting recyclables in public management. European Journal of Operational Research, v. 234, p. 839-860, 2014. https://doi.org/10.1016/j.ejor.2013.10.035

UNITED NATIONS. Development Program - UNDP. Human Development Report. 2015. Available in: http://hdr.undp.org/sites/default/files/hdr15_overview_pt.pdf. Access in: September 11, 2016.

XU, W.; ZHOU, C.; LAN, Y; JIN, J.; CAO, A. An incentive-based source separation model for sustainable municipal solid waste management in China. Waste Management \& Research, v. 33, n. 5, p. 469-476, 2015. https://doi.org/10.1177/0734242X15574979

WANG, Y.; LI, L.; KUBOTA, J.; HAN, R.; ZHU, X.; LU, G. Does urbanization lead to more carbon emission? Evidence from a panel of BRICS countries. Applied Energy, v. 168, p. 375-380, 2016. https://doi.org/10.1016/j.apenergy.2016.01.105

WANG, J.; HAN, L.; LI, S. The collection system for residential recyclables in communities in Haidian District, Beijing: A possible approach for China recycling. Waste Management, v. 28, p. 1672-1680, 2008. https://doi.org/10.1016/j.wasman.2007.05.020

WANG, H.; WANG, C. Municipal solid waste management in Beijing: characteristics and challenges. Waste Management \& Research, v. 31, p. 67-72, 2013. https://doi.org/10.1177/0734242X12468199

WALTERS, G. D. The Citation Life Cycle of Articles Published in 13 American Psychological Association Journals: A 25-Year Longitudinal Analysis. Journal of the American Society for Information Science and Technology, v. 62, n. 8, p. 1629-1636, 2011.

YANG, Z.; ZHOU, X.; XU, L. Eco-efficiency optimization for municipal solid waste management. Journal of Cleaner Production, v. 104, p. 242-249, 2015. https://doi.org/10.1016/j.jclepro.2014.09.091

ZHANG, D. Q.; TAN, S. K.; GERSBERG, R. M. Municipal solid waste management in China: Status, problems and challenges. Journal of Environmental Management, v. 91, 2010, p. 1623-1633, 2010. https://doi.org/10.1016/j.jenvman.2010.03.012

ZHAO, J.; HUANG, J.; SUN, W. On-line early fault detection and diagnosis of municipal solid waste incinerators. Waste Management, v. 28, p. 2406-2414, 2008. https://doi.org/10.1016/j.wasman.2007.11.014

ZHEN-SHAN, L.; LEI, Y.; XIAO-YAN, Q.; YU-MEI, S. Municipal solid waste management in Beijing City. Waste Management, v. 29, p. 2596-2599, 2009. https://doi.org/10.1016/j.wasman.2009.03.018

ZIA, H.; DEVADAS, V. Urban solid waste management in Kanpur: Opportunities and $\begin{array}{lllllll}\text { perspectives. Habitat International, v. 32, p. 58-73, } 2008 . & \text {. }\end{array}$ https://doi.org/10.1016/j.habitatint.2007.08.001 